\title{
A MICROECOSYSTEM FOR FERTILIZER AND PESTICIDE FATE RESEARCH ${ }^{1}$
}

\author{
B. E. Branham, D. J. Wehner, W. A. Torello, and A. \\ J. TURGEON ${ }^{3}$
}

\begin{abstract}
A microecosystem was designed to study the behavior of pesticides, fertilizers, or related compounds applied to plant stands. The system consists of three parts: a brass base that holds the plant growth media, a glass atmospheric chamber that rests on the base, and a set of analytical traps. The brass base is fitted with a porous ceramic plate so that tension can be applied to the water in the growing media. Air enters the bottom of the glass atmospheric chamber and exits through the top into appropriate trapping systems to recover volatilized pesticides, ammonia, or metabolized ${ }^{14} \mathrm{CO}_{2}$ from labeled compounds. A port at the base of the chamber allows collection of leachate. The microecosystem was evaluated by applying $\mathrm{N}$ sources or a pesticide to intact turfgrass profiles and monitoring the fate of the applied compound. Leaching and volatilization losses of $N$ ranged from 0 to $17 \%$ and 0.1 to $17 \%$ of the applied $N$, respectively, depending on $\mathbf{N}$ source, soil conditions, and whether tension was applied to the base of the system. Three weeks after the application of radiolabeled diazinon [0,0-diethyl-0-(2-isopropyl-4-methyl-6primidinyl) phosphorothiote] to a turf, $47 \%$ of the label remained in the form of the parent compound, $22 \%$ had been metabolized and lost as ${ }^{14} \mathrm{CO}_{2}, 1 \%$ had leached through the profile, $2 \%$ had been lost through volatilization, and $28 \%$ remained in the soil as a metabolite or in unextractable compounds. The microecosystem has proven to be an invaluable tool for turfgrass research and should be useful for fertilizer and pesticide fate studies with other crops.
\end{abstract}

Additional index words: Model ecosystem, Ammonia volatilization, Diazinon.

$\mathrm{M}$

ICROECOSYSTEMS are useful tools for studying the fate of pesticides, fertilizer elements, or related compounds applied to plant stands. The advantages of using these systems over field studies are that they are closed, allowing for total accountability of a compound and its metabolites and they facilitate studies with radioactive or potentially toxic materials.

The first microecosystem designed to follow the movement of pesticides and metabolites through a food chain was developed by Metcalf et al. (10), and consisted of an aquatic-terrestrial system. Cole et al. (4)

\footnotetext{
${ }^{1}$ This study was part of Project nos. 65-356 and 32-325 of the Agric. Exp. Stn., College of Agriculture, Univ. of Illinois at UrbanaChampaign, Urbana, IL 61801. Received 16 Nov. 1983. Published in Agron. J. 77:176-180.

${ }_{2}$ Assistant Professor, Dep. of Crop and Soil Sci., Michigan State Univ., East Lansing, MI 48824; Assistant Prof., Horticulture Dep., Univ. of Illinois, Urbana, IL 61801; Assistant Prof., Dep. of Plant and Soil Sci., Univ, of Massachusetts, Amherst, MA 01003; and research director, Tru-Green Corp., East Lansing, MI 48823.
} 
developed a terrestrial microecosystem composed of a $19 \mathrm{~L}$ widemouthed bell jar containing $400 \mathrm{~g}$ of vermiculite, 50 corn (Zea mays L.) seed and a five-level food chain. A pesticide was applied and the airstream was sampled periodically for volatilized pesticide. At the end of the experiment, the top level of the food chain was analyzed for the concentration of the pesticide in various organs of the body. Nash et al. (12) and Gillett and Gile (7) have developed microecosystems, however, neither system attempts to simulate field drainage.

The microecosystem presented herein was designed to allow simulation of field drainage conditions by including a porous ceramic plate under the growing media (1). The microecosystem was tested by applying fertilizers and pesticides to intact turf profiles and monitoring the fate of the applied compounds.

\section{Materials and Methods}

The microecosystem consists of three components: base, atmospheric chamber, and analytical trapping system. Eight systems are housed in a $7.3 \times 3.7 \mathrm{~m}$ controlled environment chamber. Temperature inside the microecosystems is monitored with thermocouples.

\section{Microecosystem Base}

The microecosystem base that holds soil or other growing media (Fig. 1) was constructed from $32 \mathrm{~mm}$ thick brass plate with dimensions of $208 \times 319 \times 79 \mathrm{~mm}(\mathrm{~L} \times \mathrm{W} \times \mathrm{D})$. Strips of brass $3.2 \mathrm{~mm}$ thick and $9.5 \mathrm{~mm}$ in width were soldered along the inside edge of the media base to provide a ledge upon which the porous ceramic plate rests. The ledge also forms a $3.2 \mathrm{~mm}$ deep free space on the bottom of the base. The ledge was covered with a $1.6 \mathrm{~mm}$ thick foam tape to provide an even seal for the porous ceramic plate. The porous ceramic plate (Soil Moisture Equip. Co. ${ }^{3}$ ) has dimensions of $306 \times 295 \times 13 \mathrm{~mm}$ and a bubbling pressure of $50 \mathrm{kPa}$. The plate was placed on the ledge and centered to provide a $3.2 \mathrm{~mm}$ channel along each of the four sides. An epoxy mix (Soil Moisture Equip. Co.) was layered into the channel to seal the plate into the base. A serrated hose fitting was soldered onto a corner of the base at the level of the free space to permit drainage. The hose fitting was connected by $6.4 \mathrm{~mm}$ ID teflon tubing to a 1 L Erlenmeyer flask which served to collect leachate. The filter flask was connected to a manifold which was in turn connected to a vacuum pump. The soil matric potential was constrained by the plate to be between 0 and $-50 \mathrm{kPa}$. The vacuum pump is used to apply a vacuum to the microecosystem base within the above stated range.

Along the top outside edge of the base an aluminum " $Z$ " track was attached. The " $Z$ " track formed a seat upon which the atmospheric chamber rested.

\section{Atmospheric Chamber}

The atmospheric chamber (Fig. 2) $311 \times 319 \times 356 \mathrm{~mm}$ $(\mathrm{L} \times \mathrm{W} \times \mathrm{H})$ was constructed from $6.4 \mathrm{~mm}$ plate glass. The glass was cut and drilled by the Arrow Glass Co. of Urbana, IL and assembled in the laboratory using a silicone rubber sealant. Evenly spaced $6.4 \mathrm{~mm}$ air intake holes were drilled near the bottom of each glass plate. A total of 18 intake holes were drilled per chamber. The glass section which enclosed the top of the chamber had four $19 \mathrm{~mm}$ diam holes drilled on the corners of a centered $76 \mathrm{~mm}$ square. In the

\footnotetext{
${ }^{3}$ Mention of a proprietary product does not constitute an endorsement by the Univ. of Illinois.
}

center of the square was a $11 \mathrm{~mm}$ hole. A glass manifold $(114 \times 114 \times 38 \mathrm{~mm})(\mathrm{L} \times \mathrm{W} \times \mathrm{H})$ was sealed to cover the five holes of the top glass section. A $11 \mathrm{~mm}$ diam hole was drilled in the center of the manifold which lined up directly over the hole of the same size on the glass chamber. These two holes formed the entrance for a $32 \mathrm{~mm}$ pipe to deliver water to the nozzle assembly. The nozzle assembly consisted of a full-cone spray nozzle (cat. no. 1/4 TGO.3, Spraying Systems Co., North Ave. at Schmale Rd., Wheaton, IL 60187) connected to a diaphragm body (cat. no. 8360 , Spraying Systems Co.). The nozzle assembly was attached to the $32 \mathrm{~mm}$ pipe with the use of a reducing coupler. Another hole $12.7 \mathrm{~mm}$ in diameter was offset by $25 \mathrm{~mm}$ from the center of the manifold top. A $9.5 \mathrm{~mm}$ serrated brass hole fitting was cemented to the glass with litharge $[260 \mathrm{~g} \mathrm{PbO}$ ground in a mortar with $100 \mathrm{~mL}$ of diluted glycerine $(2 / 1$, glycerine/ $\left.\mathrm{H}_{2} \mathrm{O}\right)$ ]. The brass hose fitting served as the air outtake port. The hose fitting was connected to the analytical trapping system by $9.6 \mathrm{~mm}$ ID teflon tubing.

\section{Analytical Trapping System}

The analytical trapping arrangement can be varied to meet the requirements of the particular compound being studied. Two different types of trapping systems were used to collect either pesticide-related volatiles or ammonia.

The trapping system for pesticides consisted of a solid adsorbent (chromosorb 101, Alltech and Assoc.) and was adapted from the method of Pellizzari et al. (13). An openended $7 \mathrm{~mm}$ diam glass tube was filled with $5 \mathrm{~g}$ of adsorbent and placed at the exit of the atmospheric chamber to trap

\section{MICRO ECOSYSTEM MEDIA BASE}

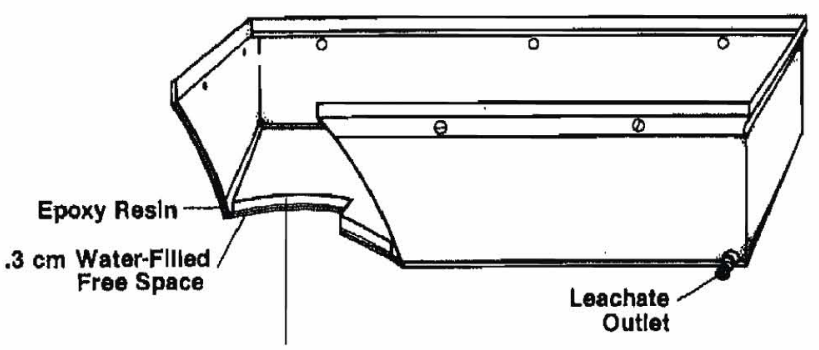

$1.3 \mathrm{~cm}$ Porous Ceramic Plate

Fig. 1. Microecosystem base.

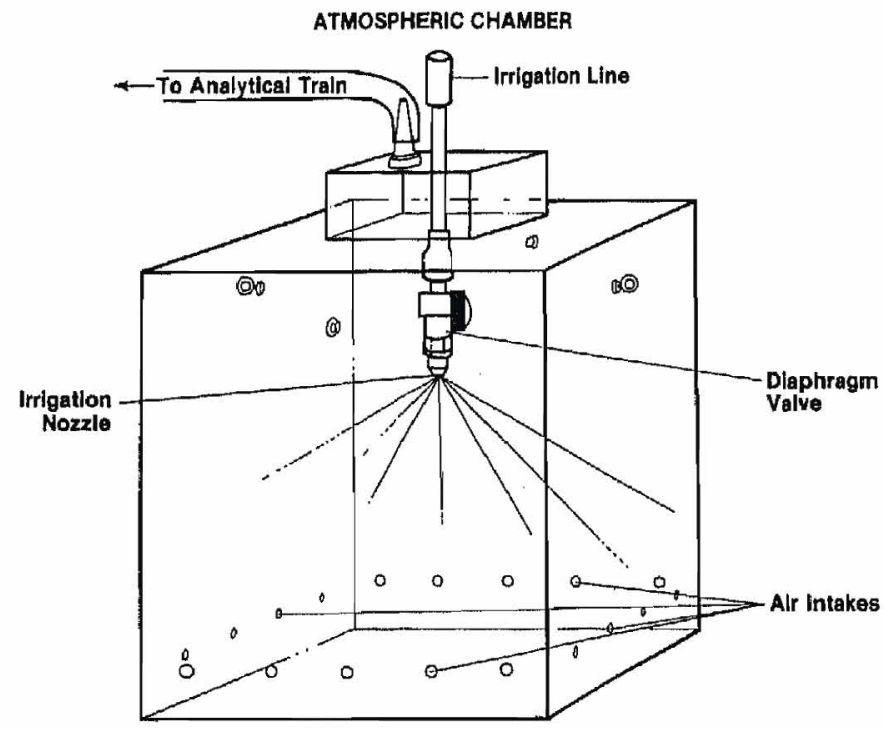

Fig. 2. Microecosystem atmospheric chamber. 
any volatilized pesticide. A second set of traps was used to scrub the airstream for any volatilized ${ }^{14} \mathrm{CO}_{2}$ resulting from the microbial degradation of the pesticide. Two flasks were filled with $375 \mathrm{~mL}$ of I $M \mathrm{NaOH}$ and the airstream was bubbled through the two traps.

In order to trap volatilized ammonia, the above trapping scheme was modified by removing the solid adsorbent trap and by using a $4.5 \mathrm{M}$ boric acid solution to trap ammonia in the two bubbling tubes.

Following either scheme, the airstream then passed through a desiccant and into an air flow meter (cat. no. VFAB-65BV, Dwyer Instruments, Inc.) to monitor and regulate air flow. The air flow meter was connected to a manifold, common to all microecosystems, that was in turn connected to a vacuum pump.

\section{Trapping Efficiency Tests}

Tests were conducted to evaluate the efficiency of trapping ${ }^{14} \mathrm{CO}_{2}$, diazinon, and $\mathrm{NH}_{3}$. $\mathrm{A}$ weighed amount of $\mathrm{Ba}^{14} \mathrm{CO}_{3}$, specific activity $1.16 \times 10^{3} \mathrm{DPM} / \mathrm{mg}$, was placed in a 10 $\mathrm{mL}$ beaker on a ringstand inside the atmospheric chamber. A buret slowly dripped $5.9 \mathrm{M}$ perchloric acid into the beaker releasing ${ }^{14} \mathrm{CO}_{2}$ over a period of $2 \mathrm{~h}$. Four bubblers connected in series were filled with $375 \mathrm{~mL}$ of $1 M \mathrm{NaOH}$ and the airstream (air flow $3.3 \times 10^{-5} \mathrm{~m}^{3} \mathrm{~s}^{-1}$ ) from the chamber was swept through the solutions for $24 \mathrm{~h}$. The solutions were collected and the radioactivity assayed by adding $3.5 \mathrm{~mL}$ of the $\mathrm{NaOH}$ solution to $15 \mathrm{~mL}$ of Aquasol (New England Nuclear). The samples were replicated three times and counted using a Packard Tri-Carb liquid scintillation counter. The solid adsorbent trap was evaluated by allowing a known amount of diazinon to volatilize in the atmospheric chamber, passing the airstream (air flow $6.6 \times 10^{-5} \mathrm{~m}^{3} \mathrm{~s}^{-1}$ ) through the adsorbent, and then extracting the diazinon from the adsorbent and assaying the amount of material trapped.

The trapping efficiency for $\mathrm{NH}_{3}$ was conducted as reported by Torello et al. (16) by dripping $1,0 \mathrm{M} \mathrm{KOH}$ into a $50 \mathrm{~mL}$ beaker containing a known amount of $\left(\mathrm{NH}_{4}\right)_{2} \mathrm{SO}_{4}$ within each atmospheric chamber. Ammonia liberated and trapped within the boric acid traps was then quantified by titrating with $0.0231 \mathrm{M} \mathrm{H}_{2} \mathrm{SO}_{4}$.

\section{Diazinon and Fertilizer Applications to Turf}

The microecosystem was evaluated by applying two different $N$ sources and the pesticide diazinon to turf and monitoring the fate of the applied compounds. In all of these evaluations, the intact turf profiles consisted of Kentucky bluegrass (Poa pratensis L.) growing on a Flanagan silt loam (fine, montmorillonitic, mesic Aquic Argiudoll). No volatilized ammonia was detected from nonfertilized controls run at the beginning of the research project. All samples were taken directly from the field and placed in the microecosystems, allowed to equilibrate for 1 to 3 days, and then fertilized or treated with diazinon. A brief outline of the procedures for these experiments is given below. Detailed accounts of the procedures are given by Torello (14) and Branham (2).

Several different fertilizer treatments were applied to turf profiles and leaching and volatilization of $N$ monitored. Ammonium nitrate (33-0-0) at the rate of $293 \mathrm{~kg} \mathrm{~N} \mathrm{ha}^{-1}$ and urea $(46-0-0)$ at the rates of 49 and $293 \mathrm{~kg} \mathrm{~N} \mathrm{ha}^{-1}$ were applied to turfs subjected to a soil moisture tension of -40 $\mathrm{kPa}$ and irrigated with $5 \mathrm{~mm}$ water every 3 days. The first irrigation came 3 days after the application of the fertilizer treatments. The temperature inside the microecosystems was $24^{\circ} \mathrm{C}$ with a $12 \mathrm{~h}$ daylength and a light irradiance of 0.204 $\mathrm{W} \mathrm{m}^{-2}$. Air flowed through the atmospheric chamber at the rate of $6.6 \times 10^{-5} \mathrm{~m}^{3} \mathrm{~s}^{-1}$ resulting in 6.7 . volume changes per hour.
Table 1. Trapping efficiencies for compounds released in microecosystem atmospheric chamber.

\begin{tabular}{llcc}
\hline Compound & $\begin{array}{c}\text { Trapping } \\
\text { agent }\end{array}$ & $\begin{array}{c}\text { Mean trapping } \\
\text { efficiency (\%) }\end{array}$ & $\begin{array}{c}\text { Standard } \\
\text { deviation }\end{array}$ \\
${ }^{14} \mathrm{CO}_{2}$ & NaOH & 98.5 & 4.4 \\
$\mathrm{Diazinon}$ & Chromosorb 101 & 89.5 & 4.9 \\
$\mathrm{NH}_{3}$ & Boric acid & 97.4 & 2.1 \\
\hline
\end{tabular}

The microecosystems were also used with the vacuum system turned off so that no tension was applied to the soil (i.e., container grown plants). In this case, urea was applied at rates of 49 and $245 \mathrm{~kg} \mathrm{~N}^{-1}$ to turf growing in a thatch layer without the accompanying soil. The thatch layer was $25 \mathrm{~mm}$ thick and had been stripped from the soil surface in the field and placed in the media base. The plant-thatch layer was irrigated with $600 \mathrm{~mL}$ distilled water and then the urea was applied. There were no subsequent irrigations.

Volatilized $\mathrm{NH}_{3}$ was collected for a 10 to 21 day period in boric acid traps and assayed as described by Torello et al. (16). The leachate was analyzed for total $\mathrm{N}$ by the Kjeldahl procedure. From one to three replications of each treatment were run.

Granular radiolabeled diazinon was applied to turf at the rate of $4.9 \mathrm{~kg} \mathrm{ha}^{-1}$ of active ingredient with enough label to provide $1.48 \times 10^{5} \mathrm{~Bq}$ of activity per microecosystem. The temperature inside the microecosystems was held at $21^{\circ} \mathrm{C}$ for $12 \mathrm{~h}$ with a light irradiance of $0.204 \mathrm{~W} \mathrm{~m}^{-2}$ and a night temperature of $16^{\circ} \mathrm{C}$. Irrigation ( $5 \mathrm{~mm}$ per application) was applied every 4 days starting immediately after pesticide application and tension was applied to the base of the microecosystem $(-40 \mathrm{kPa})$. Air flowed through the systems at a rate of $6.6 \times 10^{-5} \mathrm{~m}^{3} \mathrm{~s}^{-1}$. Volatilization, leaching, metabolism, and incorporation of the label into nonextractable soil compounds was monitored. Branham (2) presents a detailed account of the procedures for extraction of the parent compound from the soil as well as the separation of the metabolites by liquid chromatography. The volatile compounds and ${ }^{14} \mathrm{CO}_{2}$ released through pesticide metabolism were trapped as outlined in the trapping efficiency section. This experiment lasted 3 weeks.

\section{Results}

An important aspect of the microecosystems is the analytical trapping arrangement. These traps can be changed to accommodate the particular compound under investigation. Table 1 contains a summary of the trapping efficiencies for the various compounds that were released in the microecosystems. As expected, the released compounds were trapped with varying efficiencies. There were advantages to using the solid adsorbent for volatile organic compounds as it required less maintenance than wet chemical traps. The chromosorb 101 does not have much retentive capacity for water, unlike other adsorbents, e.g., molecular sieves, which proved to be inadequate as trapping materials. Also, the solid adsorbent allowed the air flow rate to be increased over the flow rate used with the wet chemical traps. A higher flow rate minimizes water condensation on the sides of the atmospheric chamber.

The losses of fertilizer $\mathrm{N}$ from the microecosystems through volatilization and leaching are presented in Table 2. These values, which are presented to demonstrate the use of the microecosystem, were recorded at various times during a research project on $\mathrm{N}$ volatilization (14) and as such cannot be directly compared with one another. However, the trends pre- 
Table 2. Volatilization and leaching losses from turf in microecosystems fertilized with urea and ammonium nitrate.

\begin{tabular}{|c|c|c|c|c|c|}
\hline \multirow[b]{2}{*}{$\begin{array}{l}\text { Nitrogen } \\
\text { source }\end{array}$} & \multirow{2}{*}{ 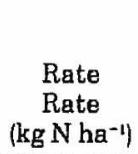 } & \multirow{2}{*}{$\begin{array}{l}\text { Suction } \\
\text { applied } \\
\text { (kPa) }\end{array}$} & \multirow{2}{*}{$\begin{array}{l}\text { Duration } \\
\text { of } \\
\text { experiment } \\
\text { (days) }\end{array}$} & \multicolumn{2}{|c|}{$\begin{array}{l}\text { Nitrogen lost } \\
\text { (\% of applied) }\end{array}$} \\
\hline & & & & $\begin{array}{l}\text { Volati- } \\
\text { lization }\end{array}$ & Leaching \\
\hline \multicolumn{6}{|c|}{ Turf without thatch on Flanagan silt loam, suction applied } \\
\hline $\begin{array}{l}\mathrm{NH}_{4} \mathrm{NO}_{3} \\
\text { Urea } \\
\text { Urea }\end{array}$ & $\begin{array}{r}294 \\
294 \\
49\end{array}$ & $\begin{array}{l}-40 \\
-40 \\
-40\end{array}$ & $\begin{array}{l}18 \\
18 \\
10\end{array}$ & $\begin{array}{l}0.1 \\
8.5 \\
1.6\end{array}$ & $\begin{array}{r}16.6 \dagger \\
11.1 \dagger \\
0.0 \dagger\end{array}$ \\
\hline \multicolumn{6}{|c|}{ Turf with thatch, no soil, no suction applied } \\
\hline $\begin{array}{l}\text { Urea } \\
\text { Urea }\end{array}$ & $\begin{array}{r}245 \\
49\end{array}$ & - & $\begin{array}{l}10 \\
10\end{array}$ & $\begin{array}{c}16.6^{* *} \\
6.6\end{array}$ & -. \\
\hline
\end{tabular}

** Means significantly different $P=0.01$.

$\uparrow$ Individual observations taken at different times. No statistical comparison possible.

sented here agree with published results of $\mathrm{N}$ volatilization experiments in regard to source and rate effects $(8,16,17)$ on $\mathrm{NH}_{3}$ losses from turf. Essentially, no $\mathrm{N}$ was lost through $\mathrm{NH}_{3}$ volatilization from turf fertilized with ammonium nitrate and volatilization losses from urea-treated turf increased with $\mathrm{N}$ application rate. The leaching loss for ammonium nitrate was higher than for the same application rate of $\mathrm{N}$ from urea. The overall low levels of $\mathrm{N}$ leached are a reflection of the nutrient holding capacity of the Flanagan silt loam and the fact that the turf samples for our study were selected from an area that had not been fertilized for 8 years. The $\mathrm{N}$ volatilization from the turfs that were not subjected to suction were higher than where tension was applied. This was probably due to the fact that more $\mathrm{N}$ remained in the turf profile in the absence of leaching, the high level of urease found in turfgrass thatch (15), and the slow drying that occurred over the course of the experiment since there were no irrigations after fertilizer application.

The results of the experiment with diazinon (Table 3 ) indicated that after 3 weeks, $47 \%$ of the applied label remained in the form of the parent compound, $22 \%$ had been metabolized and lost as ${ }^{14} \mathrm{CO}_{2}, 1 \%$ had leached through the soil profile, $2 \%$ had been lost through volatilization and $28 \%$ remained in the soil as a diazinon metabolite or in unextractable compounds. The halflife of diazinon in soil has been reported by a number of authors $(3,5,6,9,11)$ to be between 7 and 56 days depending on conditions of the experiment. Our results using the microecosystem fall within the range of previously published results.

\section{Discussion}

Because the atmospheric chambers are constructed from glass, which is opaque to ultraviolet light, no measurement of photodecomposition is possible using the microecosystems. However, most other avenues of pesticide fate can be studied. Glass was used for the atmospheric chambers so that volatile compounds would not be absorbed by the walls. No attempt was made to control the relative humidity of the air entering the atmospheric chamber.

One of the unique features of this microecosystem is the presence of the porous ceramic plate in the bottom of the media base. The plate allows a suction to be applied to the water in the soil or other growing
Table 3. Fate of radiolabeled diazinon applied to turf growing on a Flanagan silt loam.

\begin{tabular}{ccccccc}
\hline & \multicolumn{5}{c}{ Percent of applied label } \\
\cline { 2 - 7 } Week & $\begin{array}{c}\text { Lost as } \\
{ }^{14} \mathrm{CO}_{2}\end{array}$ & Leached & $\begin{array}{c}\text { Vola- } \\
\text { Vola- } \\
\text { tilized }\end{array}$ & $\begin{array}{c}\text { As unex- } \\
\text { tractable } \\
\text { compounds }\end{array}$ & $\begin{array}{c}\text { Metabo- } \\
\text { lite }\end{array}$ \\
\hline 1 & $0.3 \ddagger$ & 0.5 & 1.3 & 16.2 & 6.1 & 7550 \\
2 & 4.4 & 0.9 & 2.0 & 16.3 & 7.3 & 69.1 \\
3 & 22.2 & 1.2 & 2.0 & 23.4 & 4.0 & 47.2 \\
\hline
\end{tabular}

$\dagger$ 2-isopropyl-4-methyl-6-hydroxypyrimidine.

$\$$ Values represent mean of two replications.

media. Because the soil base is only $50 \mathrm{~mm}$ deep, caution must be used in interpreting leaching data. For herbicide research the depth is adequate because very few weed seeds germinate below $50 \mathrm{~mm}$ in the soil. Herbicide that is leached out of the $50 \mathrm{~mm}$ zone would no longer be effective. Also, cool-season turfgrasses which have a fairly shallow root system under mowed conditions lend themselves to this depth. No attempts were made to determine the amount of nutrient or radioactive label that may be adsorbed to the ceramic plate. The use of a balance sheet approach in studying applied compounds will allow the researcher to determine if this is important.

In summary, the microecosystems have proven to be useful for carrying out studies on the fate of pesticides and fertilizers applied to turfgrass stands. They should be adaptable to other plant species by changing the system dimensions and trapping arrangements to suit the goals of the researchers. Experimental conditions, such as soil moisture, can be varied so that simple comparisons between soil type, plant species, etc. can be easily accomplished.

\section{Acknowledgments}

The authors wish to thank Drs. L. A. Spomer, R. F. Nystrom, and Mr. Howard Friese for their help with this project.

\section{References}

1. Branham, B.E. 1980. Development of a microecosystem for determining the fate of pesticides in turf. M.S. Thesis. Univ. of Illinois, Urbana.

2. 1983. The fate of DCPA and diazinon in turf using model ecosystems. Ph.D. thesis. Univ. of Illinois, Urbana.

3. Bro-Rasmussen, E. Noddegaard, and K. Voldum-Clausen, 1968. Degradation of diazinon in soil. J. Sci. Food Agric. 19:278-281.

4. Cole, L.K, J.R. Sanborn, and R.L. Metcalf. 1976. Inhibition of corn growth by Aldrin and the insecticide's fate in the soil, air, crop and wildlife of a terrestrial model ecosystem. Environ. Entomol. 5(3):583-589.

5. Getzin, L.W. 1968. Persistence of diazinon and zinophos in soil: effects of autoclaving, temperature, moisture, and acidity. $J$. Econ. Entomol. 61(6): $1560-1565$.

6. Getzin, L.W., and I. Rosefield. 1966. Persistence of diazinon and zinophos in soils. J. Econ. Ent. 59(3):512-516.

7. Gillett, J.W., and J.D. Gile. 1976. Pesticide fate in terrestrial laboratory ecosystems. Int. J. Environ. Studies 10:15-22.

8. Kissel, D.E., H.S. Brewer, and G.F. Arkin. 1977. Design and test of a field sampler for ammonia volatilization. Soil Sci. Soc. Am. J. 41:1133-1138.

9. Malone, C.R., A.G. Winnett, and K. Helrich. 1967. Insecticide induced responses in an old field ecosystem: persistence of diazinon in soil. Bull. Environ. Contam. Toxicol. 2:83-89.

10. Metcalf, R.L., G.K. Sangha, and I.P. Kapoor. 1971. Model ecosystem for the evaluation of pesticide biodegradability and ecological magnification. Environ. Sci. Tech. 5:709-713.

11. Miles, J.R.W., C.M. Tu, and C.R. Harris. 1979. Persistence of eight organophosphorous insecticides in sterile and non-sterile mineral and organic soils. Bull. Environ, Contam. Toxicol. 22:312-318. 
12. Nash, R.G., M.L. Beall Jr., and W.G. Harris. 1977. Toxaphene and 1,1,1-trichloro-2,2-bix-(p-chlorophenyl) ethane (DDT) losses from cotton in an agroecosystem chamber. J. Agric. Food Chem. $25(2): 336-341$.

13. Pellizzari, E.D., J.E. Bunch, R.E. Berkley and J. McRae. 1976. Collection and analysis of trace organic vapor poilutants in ambient atmospheres. The performance of a tenax GC cartridge sampler for hazardous vapors. Anal. Lett. 9(1):45-63.

14. Torello, W.A. 1981. Ammonia volatilization and urease activity in turf. Ph.D. thesis. Univ. of Illinois, Urbana.

15. Torello, W.A. and D.J. Wehner. 1983. Urease activity in a Kentucky bluegrass turf. Agron. J. 75:654-656.

16. Torello, W.A., D.J. Wehner and A.J. Turgeon. 1983. Ammonia volatilization from fertilized turfgrass stands. Agron. J. 75:454456.

17. Volk, G.M. 1959. Volatile loss of ammonia following surface application of urea to turf or bare soils. Agron. J, 51:746-749. 